\section{Hand wasting in calumny of Apelles}

\section{Sanjay Sharma \\ Department of Neurology, Ramkrishna Care Hospital, Rajpur (CG), India}

\begin{abstract}
Renaissance painting from the early 15 th to the mid-16th centuries originated in the area of present-day Italy. Inspired by the works of ancient Greece and Rome, artists produced painting based on topographic observation and the idealistic body proportion. Most of the paintings depict the human figure in perfect shape.
\end{abstract}

"The Calumny of Apelles" was painted by the Italian painter Sandro Botticelli. It depicts a dark male figure painted in the center with bilateral symmetrical distal wasting of limbs and poor body frame. The unusual portrayal may also suggest use of a live model suffering from lead toxicity.

"The Calumny of Apelles" was painted by the gifted Renaissance master Sandro Botticelli around 1494-1495. The theme subject was drawn from a painting by the Greek artist Apelle. The dramatic court scene is of an innocent man who is dragged before the king. Various human figures representing emotions are scattered around the canvas. A dark male figure painted in the center has been identified as Envy, deformed and shrunken as from long illness. ${ }^{1}$ Envy has noticeable wasting of muscles in both hands. The outstretched left hand showed atrophied first dorsal interosseous and muscles of the forearm compartment including brachioradialis and deep flexors producing longitudinal grooves on both sides of the radius bone. The right hand shows marked atrophy in the extensor compartment of the forearm. The exposed part of the legs reveals calf atrophy. The pattern is observed in multiple neuro muscular disorders including advanced lead neuropathy affecting limbs. The Renaissance era was known for excellent knowledge of human anatomy and extensive use of colors. Lead was a key component of the pigment in many paints. Lead toxicity is reported in painters and pottery workers. ${ }^{2,3,4}$ However, the common source of lead toxicity was consumption of metal in various ways.

Lead touched many areas of Roman life. It was used to make cosmetics and coins. The other early use of lead was for the strips joining the pieces of colored glass in church windows. The ancient Romans used lead for making water pipes. Lead's sweet overtones were thought to add complementary flavors to wine and to food as well. ${ }^{5}$ It was argued that lead poisoning contributed to the decline of the Roman Empire, ${ }^{6,7}$ and had been criticized by others. ${ }^{8}$ Romans began to suspect a connection between the metal and disease; however, their cultural habits never changed. Some historians believed that many among the Roman aristocracy suffered from lead poisoning.

Motor neuropathy, delirium, and hallucinations are common neurological manifestations of lead toxicity in adults. The neuropathy is typically accompanied by other systemic features of lead toxicity that includes anemia (microcytic, hypochromic) with plumbic skin tone, gastrointestinal disturbance (constipation, abdominal pain), renal dysfunction, fatigue and weight loss. The neuropathy associated with lead toxicity develops insidiously with chronic exposure. The classic clinical manifestations are predominantly motor with paucity of sensory symptoms or signs. The typical pattern is distal, symmetric weakness with atrophy and occasionally fasciculation that may involve the arms relatively early ${ }^{9,10}$ and
Correspondence: Sanjay Sharma,

Department of neurology, Ramkrishna Care Hospital, Rajpur (CG), India.

E-mail: drsanjaysharma123@rediffmail.com

Key words: hand wasting, botticelli, lead toxicity, lead neuropathy, neurology, medicine, brain, neurosurgery.

Received for publication: 11 July 2009.

Revision received: 28 July 2009.

Accepted for publication: 28 July 2009.

This work is licensed under a Creative Commons Attribution 3.0 License (by-nc 3.0)

(C) Copyright S. Sharma et al., 2009 Licensee PAGEPress, Italy

Neurology International 2009; 1:e12 doi:10.4081/ni.2009.e12

sometimes resemble amyotrophic lateral sclerosis. ${ }^{11}$ The symmetric or asymmetric wrist drop is common; lower extremity involvement with foot drop, may also occur. The electrodiagnostic studies reveal mild motor conduc-

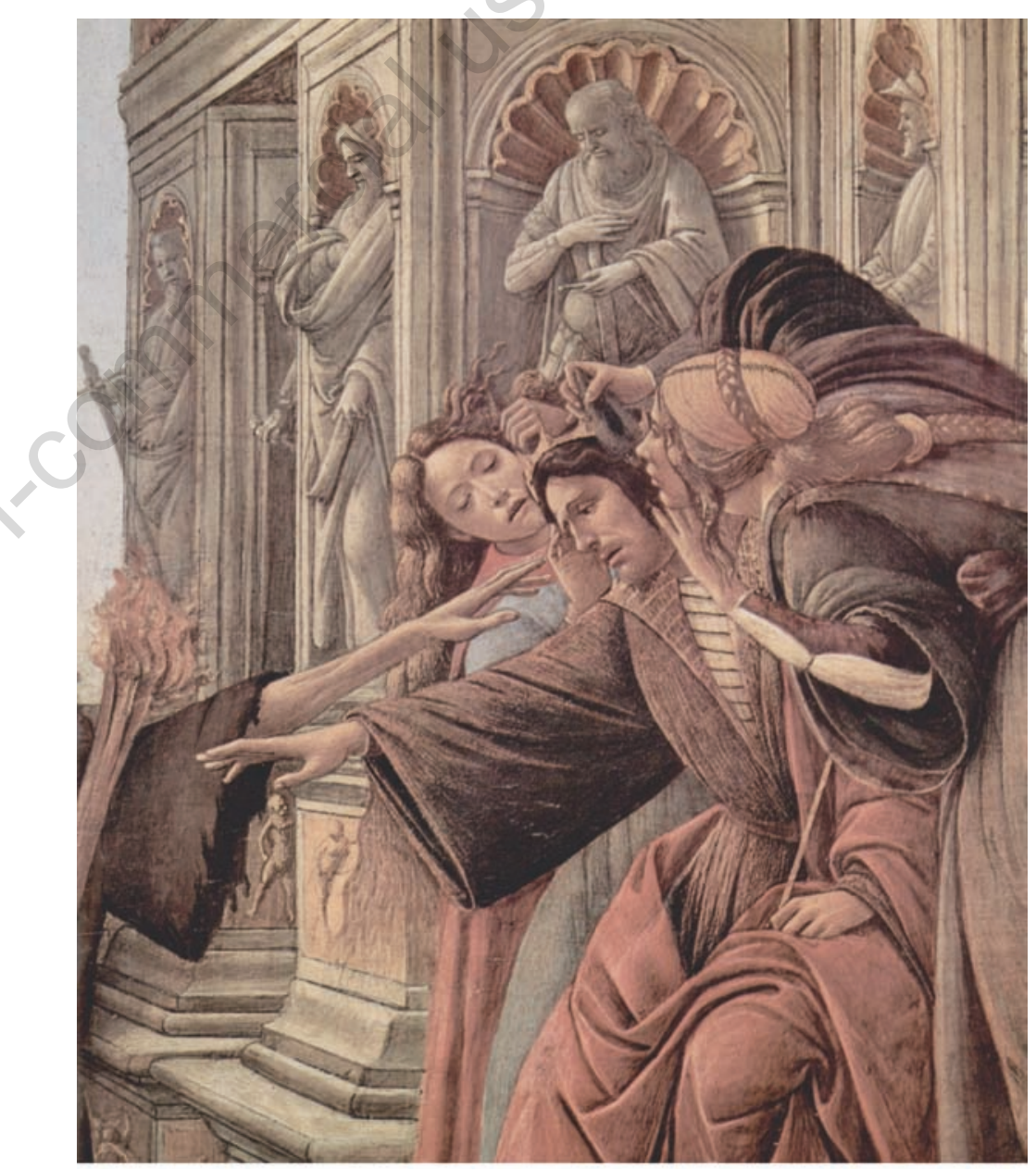

Figure 1. "The Calumny of Apelles" painting (detail) by Sandro Botticelli showing left hand of the character Envy with wasted first dorsal interosseous, dropped fourth and fifth digit, and atrophied muscle in forearm. 
tion slowing to axonal features with frank electromyography denervation. ${ }^{12}$ A painful sensory and autonomic neuropathy associated with elevated blood or urine lead levels was also reported with length dependent exposure in a group of workers. ${ }^{13}$

Envy in "The Calumny of Apelles" by Botticelli represents an effective portrayal of bilateral symmetric distal wasting in a man affecting his upper extremities more than lower as shown in Figures 1 and 2. Generally distal weakness and wasting suggests a neuropathic process. It fits the description of motor neuropathy associated with chronic lead toxicity, the mysterious malady of that era.

\section{References}

1. Calumny of Apelles (Botticelli). (2009, May 14). In Wikipedia, The Free Encyclopedia. http://en.wikipedia.org/w/ index.php?title=Calumny_of_Apelles_(Bo tticelli)\&oldid=289878951 Accessed 13:46, May 14, 2009.

2. Fischbein A, Wallace J, Sassa S, et al. Lead poisoning from art restoration and pottery work: unusual exposure source and household risk. J Environ Pathol Toxicol Oncol 1992; 11:7-11.

3. Weissman E. Vincent van Gogh (185390): the plumbic artist. J Med Biogr 2008; 16:109-17.

4. Wells EV. Lead toxicity in a house painter. J Tenn Med Assoc 1992; 85:519-22.

5. Waldron HA. Lead poisoning in the ancient world. Med History 1973;17: 391-9.

6. Gilfillan SC. Lead Poisoning and the fall of Rome. J Occupation Med 1965;1:53-60.

7. Nriagu JO. Saturnine gout among roman aristocrats: did lead poisoning contribute to the fall of the Empire? $\mathrm{N}$ Engl $\mathrm{J}$ Med 1983;308:11: 660-3.

8. Scarborough J. The myth of lead poisoning among the Romans: a review essay". J History Med Allied Sci 1984;39:4:469-75.

9. Gordon AH. Clinical lecture on lead Neuropathy. Can Med Assoc J 1924;14: 479-81.

10. Cullen MR, Robins JM, Eskenazi B. Adult inorganic lead intoxication: presentation of 31 cases and a review of recent

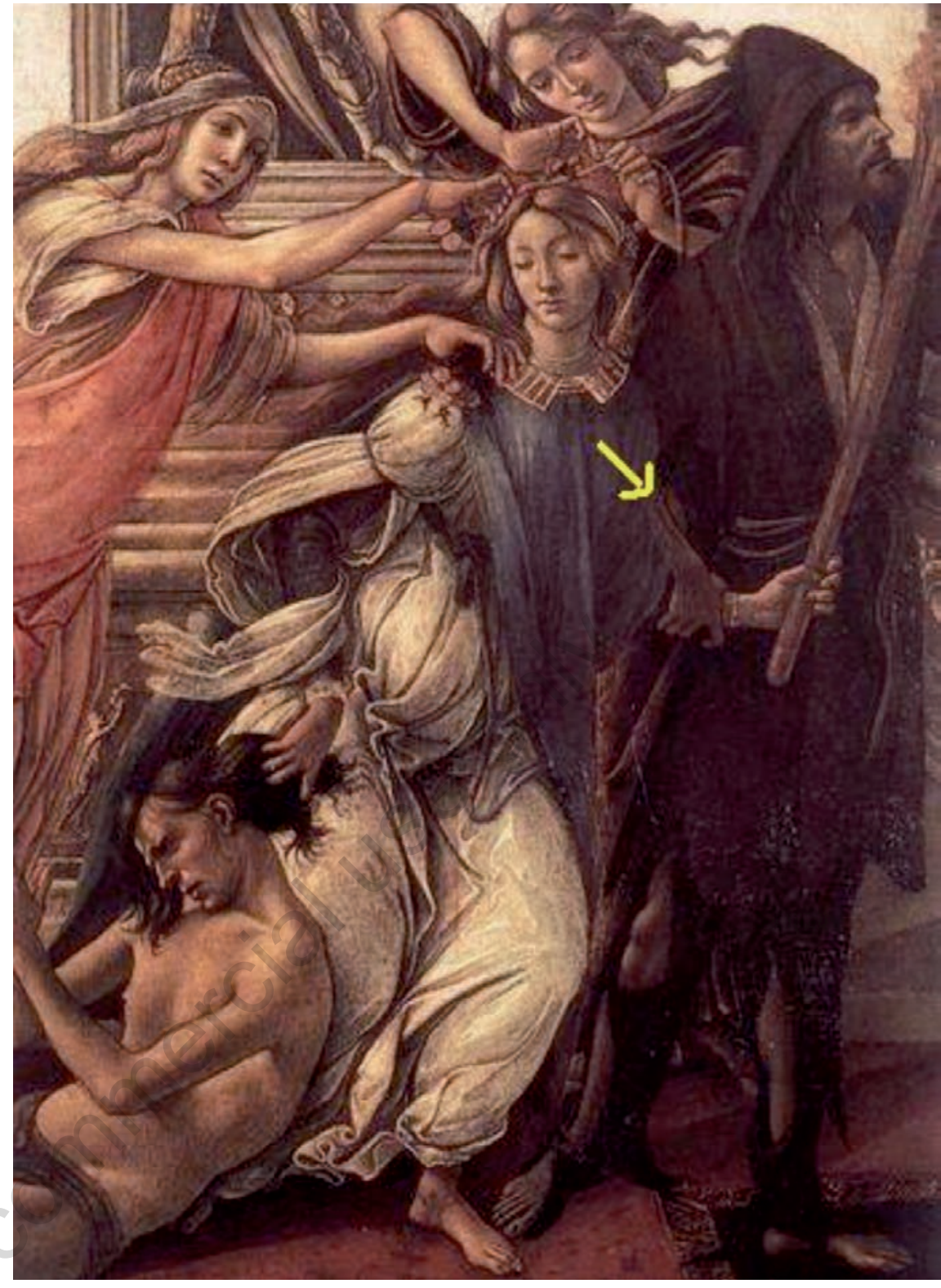

Figure 2. The profile of Envy. Note wasting in extensor aspect of forearm, weak grip of right hand (yellow arrow) and wasted calf muscles.

advances in the literature. Medicine 1983; 62:221-47.

11. Livesley B, Sissons CE. Chronic lead intoxication mimicking motor neurone disease. Br Med J 1968; 4:387-8.

12. Windebank AJ. Metal neuropathy. In: Dyck PJ, Thomas PK editors. Peripheral neu- ropathy. 3rd ed. Philadelphia: WB Saunders 1993:1549-70.

13. Rubens 0, Logina I, Kravale I, et al. Peripheral neuropathy in chronic occupational inorganic lead exposure: a clinical and electrophysiological study. J Neurol Neurosurg Psychiatry 2001;71:200-4. 